PREPARED FOR THE U.S. DEPARTMENT OF ENERGY, UNDER CONTRACT DE-AC02-76CH03073

PPPL-3647

PPPL-3647

UC-70

Industrial Hygiene Concerns during the Decontamination and Decommissioning of the Tokamak Fusion Test Reactor

by

M.E. Lumia and C.A. Gentile

January 2002

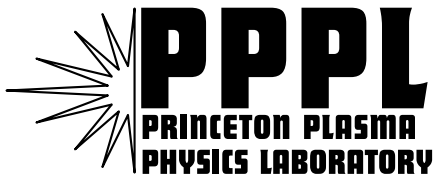

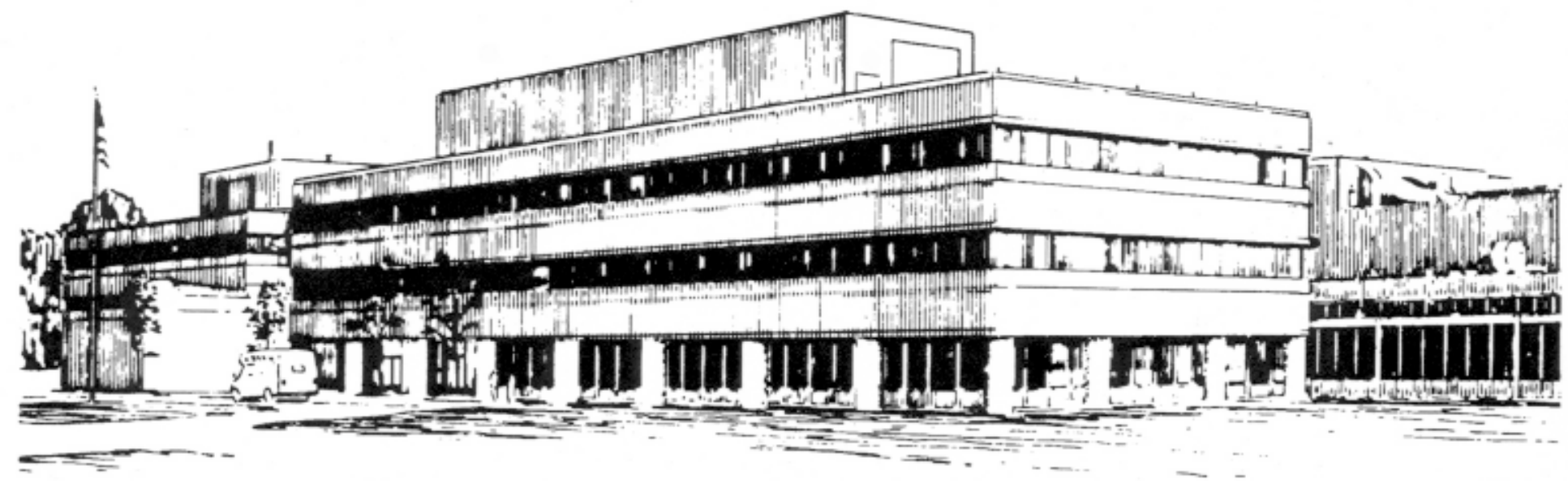

PRINCETON PLASMA PHYSICS LABORATORY PRINCETON UNIVERSITY, PRINCETON, NEW JERSEY 


\section{PPPL Reports Disclaimer}

This report was prepared as an account of work sponsored by an agency of the United States Government. Neither the United States Government nor any agency thereof, nor any of their employees, makes any warranty, express or implied, or assumes any legal liability or responsibility for the accuracy, completeness, or usefulness of any information, apparatus, product, or process disclosed, or represents that its use would not infringe privately owned rights. Reference herein to any specific commercial product, process, or service by trade name, trademark, manufacturer, or otherwise, does not necessarily constitute or imply its endorsement, recommendation, or favoring by the United States Government or any agency thereof. The views and opinions of authors expressed herein do not necessarily state or reflect those of the United States Government or any agency thereof.

\section{Availability}

This report is posted on the U.S. Department of Energy's Princeton Plasma Physics Laboratory Publications and Reports web site in Fiscal Year 2002. The home page for PPPL Reports and Publications is: http://www.pppl.gov/pub_report/

DOE and DOE Contractors can obtain copies of this report from:

U.S. Department of Energy

Office of Scientific and Technical Information

DOE Technical Information Services (DTIS)

P.O. Box 62

Oak Ridge, TN 37831

Telephone: (865) 576-8401

Fax: (865) 576-5728

Email: reports@adonis.osti.gov

This report is available to the general public from:

National Technical Information Service

U.S. Department of Commerce

5285 Port Royal Road

Springfield, VA 22161

Telephone: 1-800-553-6847 or

(703) 605-6000

Fax: (703) 321-8547

Internet: http://www.ntis.gov/ordering.htm 


\title{
INDUSTRIAL HYGIENE CONCERNS DURING THE DECONTAMINATION AND DECOMMISSIONING OF THE TOKAMAK FUSION TEST REACTOR
}

\author{
M. E. LUMIA AND C. A. GENTILE \\ Princeton Plasma Physics Laboratory, P.O. Box 451, Princeton NJ 08543
}

\begin{abstract}
A significant industrial hygiene concern during the Decontamination and Decommissioning (D\&D) of the Tokamak Fusion Test Reactor (TFTR) was the oxidation of the lead bricks' surface, which were utilized for radiation shielding. This presented both airborne exposure and surface contamination issues for the workers in the field removing this material. This paper will detail the various protection and control methods tested and implemented to protect the workers including those technologies deployed to decontaminate the work surfaces. In addition, those techniques employed to recycle the lead for additional use at the site will be discussed.
\end{abstract}

\section{INTRODUCTION}

Lead dust is a severe hazard to those who are over exposed. Lead differs from many metals, in that it serves no biological function. Many other metals are necessary nutrients found at low concentrations in humans. When lead dust is inhaled, it is readily absorbed and distributed throughout the body. Repeated exposures can cause a gradual accumulation of lead, particularly in the bones. Symptoms of chronic exposure can include anxiety, weakness, headaches, tremors, excessive tiredness and other indicators of nervous damage.

Lead can enter the body through either the gastrointestinal or the respiratory tract. Lead is readily absorb from the lung and is the predominate route of exposure in occupational settings. The OSHA PEL (Permissible Exposure Limit) is $30 \mathrm{ug} / \mathrm{m} 3$ [1]. The quantity of lead absorbed depends on the particle size, respiratory volume and rate, and mucociliary and alveolar clearance mechanisms. Approximately $35 \%$ to $40 \%$, of the total lead inhaled, actually enters the blood [2]. The OSHA biological-monitoring standard for blood lead is a maximum concentration of $50 \mathrm{ug} / 100 \mathrm{ml}$ whole blood [1]. Blood sampling analysis is mandatory every 6 months for workers exposed above the PEL for more than 30 days per year [3].

Once the lead enters the blood it binds to erythrocytes (a mature red blood cell). Over the next few weeks it is distributed to those tissues that receive high blood flow, such as, kidney, liver, and brain. Bone has the highest affinity for lead. Biophysically, lead resembles calcium, which may explain its high affinity for bone [2]. The total content of lead in the organism is called the body burden. About $90 \%$ of the body burden of lead is found in the bones. Numerous studies have shown that lead follows the metabolism of calcium [4].
The safe removal of lead shielding at Princeton Plasma Physics Laboratory was a major component of work, during the Tokamak Fusion Test Reactor (TFTR) Decontamination and Decommissioning (D\&D) Project. The physical aspects of this project commenced at the beginning of October 1999

Throughout the years of 1999, 2000, and 2001 approximately 250,000 pounds of lead was safely removed from the TFTR test cell and test cell basement. Typically, the lead was in the form of bricks each weighing approximately 27 pounds. The lead bricks were used as radiation shielding around TFTR's diagnostics. After years of use, many of the bricks were observed to be coated with a layer of white powder. Analysis of this powder revealed inorganic lead. During the removal of the bricks, this powder had a tendency to become airborne and eventually resettled on other surfaces throughout the work area. This re-deposition was a serious concern in the TFTR Test Cell and Test Cell Basement where there was a high number of workers performing collateral tasks associated with TFTR D\&D.

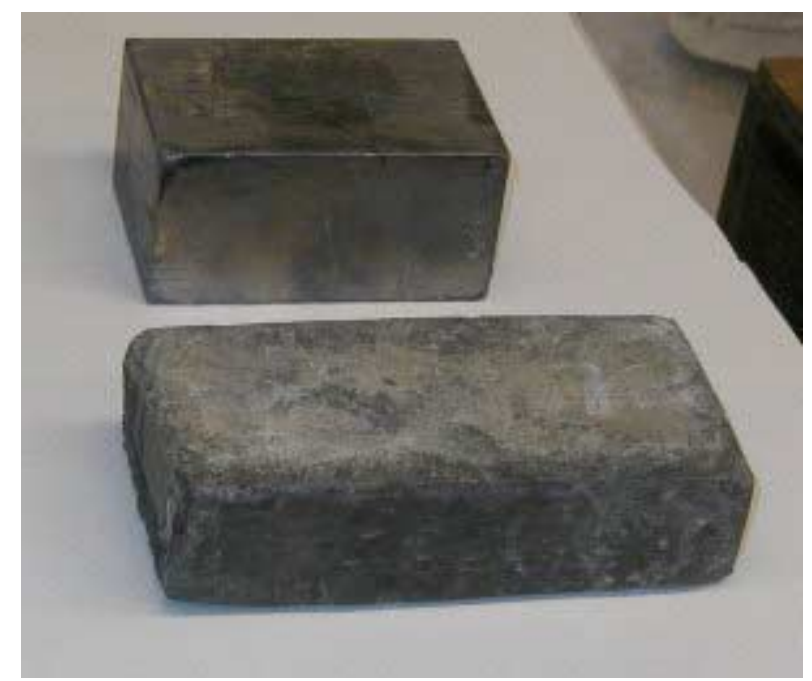

Fig. 1 the top lead brick exhibits no oxidized surface dust. The bottom lead brick exhibits oxidized surface dust.

A search of the Occupation Safety and Health Administration (OSHA) standards was conducted for exposure limits for lead dust as a surface contaminate. No such standard could be located. However the general duty clause, Section 5(a)(1) of the Occupation Safety and Health Act of 1970 "applies to all employers and required each employer to provide employees with a place of employment that is free of 
recognized hazards that may cause death or serious physical harm" [5]. Since there was no specific OSHA standard available and the laboratory was required to rid the area of the lead dust, the Industrial Hygienists reviewed the Housing and Urban Development (HUD) standard. HUD had standards for surface contamination. The HUD standard for lead screening was adopted as a guideline [6].

Samples of the different surfaces were collected using OSHA's sampling for surface contamination techniques. The wipe sample results determined that the level of dust was well above the HUD guidelines. Four different methods were employed to reduce the quantity of lead oxide exposure to personnel which included using a HEPA (high efficiency particulate Air) filter vacuum and wiping the material down with Windex TM, and adhesive pad, strippable paint, and acetic acid. After testing with various paints, it was found that coating the bricks with Rust-oleum Rust-O-Than TM epoxy based paint allowed the bricks to be reused in the future and reduce the development of lead oxide.

\section{METHODS AND MATERIALS}

Three areas of the TFTR Test Cell basement had diagnostic equipment with the lead brick shielding After each area was cleared of the lead bricks, the workers wiped the surface areas down with Windex ${ }^{\mathrm{TM}}$ and then used a High Efficiency Particulate Air Filter vacuum (HEPA) to remove any lead dust. No initial samples were taken, as it was assumed the lead concentration was above the HUD guidelines. Once this was completed, the areas were sampled to see if any lead dust remained. The sampling techniques described in the OSHA Technical Manual, Chapter 2 "Sampling for surface contamination" were used. Areas sampled initially were marked to avoid sampling the same area again. The marked area was measured and recorded. The area of the sample was calculated. Using a "Lead Wipe TM" brand wipe, the area was wiped starting at the outside edge and progressing towards the center of the surface area. The sample wipe was folded over with the exposed side in and placed into a plastic vial, labeled, and sent to an off site laboratory for analysis [7]. The sample concentration was converted to $\mu \mathrm{g} / \mathrm{ft}^{2}$ by dividing the results by the calculated area. The analytical method used by the outside laboratory was the modified NIOSH 7300 method.

In accordance with the NIOSH Manual of Analytical Methods, the samples were placed in a clean beaker followed by the addition of ashing acid (HNO3:HClO4) [8]. The sample is then coverd with a watchglass. The sample is then left to stand for 30 minutes at room temperature, then heated on a hotplate until $0.5 \mathrm{ml}$ remains. Ashing agent continues to be added to the sample and it is heated until the solution is clear. The watchglass is removed and the sample is rinsed into the beaker with distilled water. The temperature of the hot plate is increased and the sample is brought to near dryness. The residue is dissolved in dilution acid and the solutions are transferred to flasks. The samples are then analyzed using an inductively coupled plasma-atomic emission spectrometer [8].

The first results showed that the surface contamination was above the HUD surface contamination guidelines. These areas were then wiped down again and re-vacuumed with the HEPA vacuum and re-sampled. When the results were returned, it was found that the metal structural surfaces were below the HUD guidelines. It was decided that the wooden pieces would be disposed of as hazardous waste. The concrete floor surfaces however, were still well above the guidelines.

Next, an adhesive pad was placed down in a designated area. Pressure was applied to the pad and then it was removed and discarded as hazardous waste. The area was sampled and the results indicated levels were lower still; however, the levels were still above the HUD guidelines.

The next mitigating method used was strippable paint. Stripcoat TLC Free TM was applied to a small area and left to dry over night. The directions for the strippable paint suggest spraying the paint onto the surface; However, a thick coat was needed to properly remove the contamination. Therefore, the paint was poured onto the floor and spread with a roller. After approximately 24 hours the paint was peeled and the floor was re-sampled. The results were below the HUD standard. Next the entire contaminated floor was painted and allowed to dry, again for 24 hours. The following day when the paint was to be peeled, it was discovered that paint was not applied in a thick enough fashion. A second layer of paint was applied and allowed to dry overnight. The following day the paint was peeled and the area was sampled. Once again the results were below the HUD guidelines. For the remainder of the floor area, each section was wiped down with Windex and vacuumed to remove the lose dust and then the strippable paint was applied. After the paint dried and was removed the areas were sampled and declared clean if the results came back below the guideline. One area had to be repainted to get the levels below the guideline.

The last mitigating method that was used was a 5\% Acetic acid solution. After the bricks were removed the area was wiped down using the acetic acid solution. The area was sampled and the results were below the guideline.

After all the bricks were collected, they were placed in a box to later be coated in polyurethane. This coating would allow the bricks to be used in future projects. Workers handling the coated bricks would not need respiratory protection. And the coating would reduce future oxidation of the bricks. 


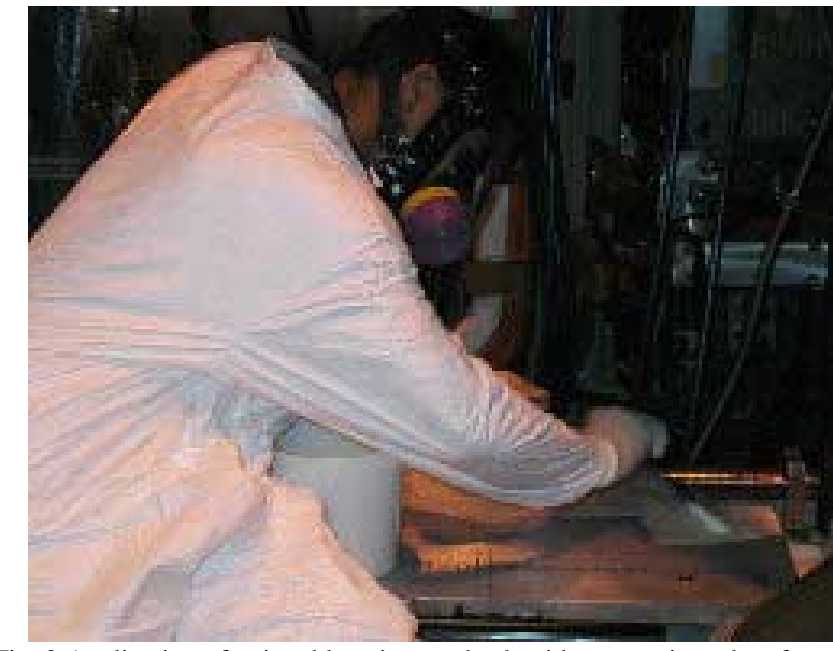

Fig. 2 Application of strippable paint to a lead oxide contaminated surface.

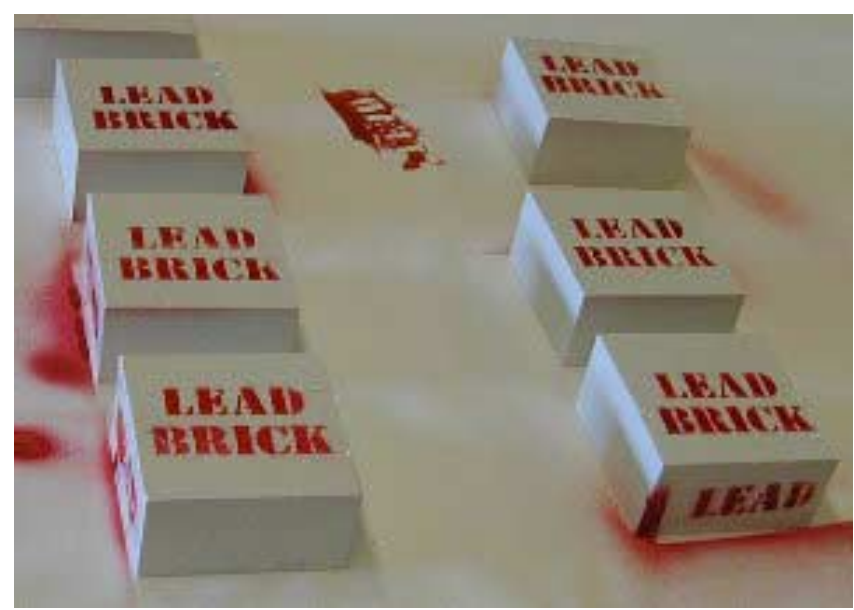

Fig.3 Lead bricks coated with polyurethane and labeled for future use.

IV Results

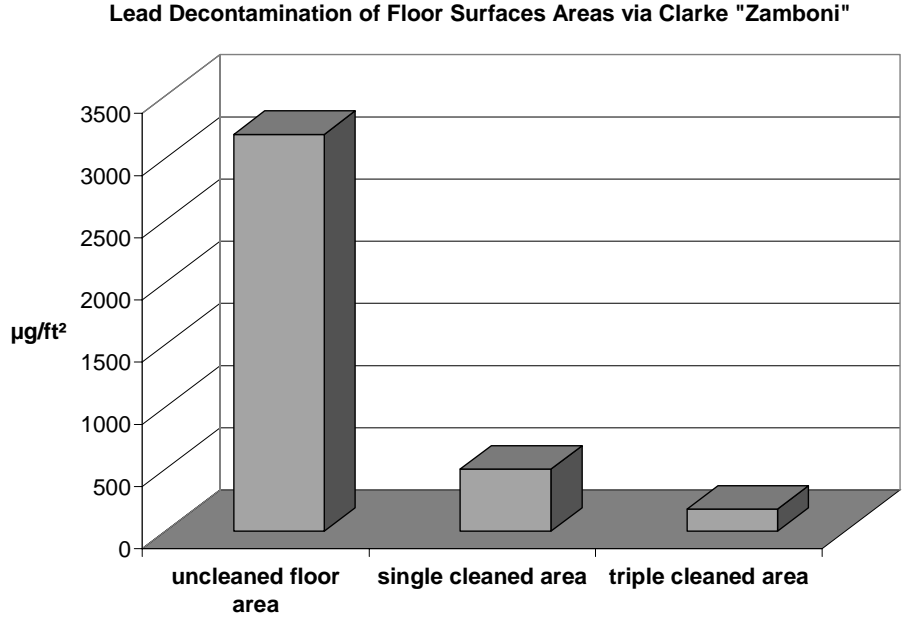

Fig. 4 This technique did not mitigate the lead oxide surface dust to below the HUD guidelines

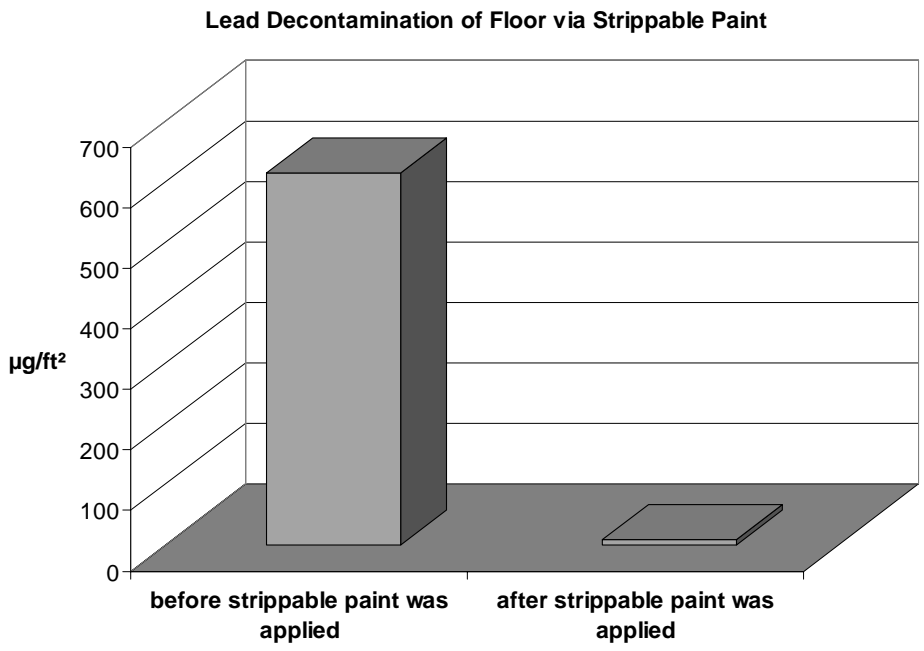

Fig. 5 This technique was successful in reducing the lead oxide surface dust to below the HUD guidelines.

\section{Conclusion}

To the knowledge of the authors and after an extensive literature search, it was concluded that this was the first time strippable paint was applied as a mitigation technique for the safe removal of lead oxide surface dust contamination.

After various techniques, including water, Windex ${ }^{\mathrm{TM}}$, Acetic acid, and sticky pads, were used it was determined that the application of the Stripcoat TLC Free TM strippable paint provided the most effective means of removing lead oxide surface dust. This technique was both highly effective in reducing lead oxide surface dust and cost effective, due to the single application process.

It was determined that for non-flat surface areas with slight lead oxide surface dust contamination, such as pipes, that a 5\% acetic acid solution was effective. However, this process had to be repeated several times before the lead oxide surface dust contamination levels were below the HUD guideline

It is recommended by the authors that for flat porous surfaces, with contaminated lead oxide surface dust, that the strippable paint be utilized to reduce the level of this toxic material to acceptable level, in this case below the HUD guidelines.

\section{ACKNOWLEDGMENT}

The authors wish to thank the efforts of Eugene Kearns, Alan Planetta, Thomas Guttadora, Robert Tucker, Jr., Tyrone Dotson, and Robert Carnevale for the safe removal of lead from TFTR and their part in preparing the lead for additional (future) use. 


\section{References}

[1] "Lead Standard," Code of Federal Regulations, Title 29 Part 1910.1025, Occupational Safety and Health Administration, Washington, D.C., 1979

[2] M. Greenberg, R. Hamilton, S. Phillips, Occupational, Industrial, and Environmental Toxicology, Boston: Mosby, 1997, pp295-299

[3] S. DiNardi, The Occupational Environment-Its Environment and Control, Fairfax: AIHA Press 1997, pp264-266

[4] C. Zenz, Occupational Medicine, $3^{\text {rd }}$ ed., Boston: Mosby 1994, pp514519

[5] "Duties," Section 5(a)(1) The Occupation Safety and Health Act ,1970

[6] "Requirements for Notification, Evaluation, and Reduction of Leadbased Paint Hazards in Federally Owned Residential Property and Housing Receiving Federal Assistance; Final Rule," Code of Federal Regulations, Department of Housing and Urban Development 24 CFR Part 35, 1999

[7] “OSHA Technical Manual-Section II Chapter 2," Occupational Safety and Health Administration, U.S. Dept. of Labor, Washington, D.C.

[8] "Elements (ICP): Method 7300, Issue 2" National Institute of Occupational Safety and Health Manual of Analytical Methods (NMAM) $4^{\text {th }}$ ed., 1994 


\section{External Distribution}

Plasma Research Laboratory, Australian National University, Australia

Professor I.R. J ones, Flinders University, Australia

Professor J oão Canalle, Instituto de Fisica DEQ/IF - UERJ , Brazil

Mr. Gerson O. Ludwig, Instituto Nacional de Pesquisas, Brazil

Dr. P.H. Sakanaka, Instituto Fisica, Brazil

The Librarian, Culham Laboratory, England

Library, R61, Rutherford Appleton Laboratory, England

Mrs. S.A. Hutchinson, JET Library, England

Professor M.N. Bussac, Ecole Polytechnique, France

Librarian, Max-Planck-Institut für Plasmaphysik, Germany

J olan Moldvai, Reports Library, MTA KFKI-ATKI, Hungary

Dr. P. Kaw, Institute for Plasma Research, India

Ms. P.J . Pathak, Librarian, Insitute for Plasma Research, India

Ms. Clelia De Palo, Associazione EURATOM-ENEA, I taly

Dr. G. Grosso, Instituto di Fisica del Plasma, Italy

Librarian, Naka Fusion Research Establishment, J AERI, J apan

Library, Plasma Physics Laboratory, Kyoto University, J apan

Research Information Center, National Institute for Fusion Science, J apan

Dr. O. Mitarai, Kyushu Tokai University, J apan

Library, Academia Sinica, Institute of Plasma Physics, People's Republic of China

Shih-Tung Tsai, Institute of Physics, Chinese Academy of Sciences, People's Republic of China

Dr. S. Mirnov, TRINITI, Troitsk, Russian Federation, Russia

Dr. V.S. Strelkov, Kurchatov Institute, Russian Federation, Russia

Professor Peter Lukac, Katedra Fyziky Plazmy MFF UK, Mlynska dolina F-2, Komenskeho Univerzita, SK-842 15 Bratislava, Slovakia

Dr. G.S. Lee, Korea Basic Science Institute, South Korea

Mr. Dennis Bruggink, Fusion Library, University of Wisconsin, USA

Institute for Plasma Research, University of Maryland, USA

Librarian, Fusion Energy Division, Oak Ridge National Laboratory, USA

Librarian, Institute of Fusion Studies, University of Texas, USA

Librarian, Magnetic Fusion Program, Lawrence Livermore National Laboratory, USA

Library, General Atomics, USA

Plasma Physics Group, Fusion Energy Research Program, University of California at San Diego, USA

Plasma Physics Library, Columbia University, USA

Alkesh Punjabi, Center for Fusion Research and Training, Hampton University, USA

Dr. W.M. Stacey, Fusion Research Center, Georgia Institute of Technology, USA

Dr. J ohn Willis, U.S. Department of Energy, Office of Fusion Energy Sciences, USA

Mr. Paul H. Wright, Indianapolis, Indiana, USA 
The Princeton Plasma Physics Laboratory is operated by Princeton University under contract with the U.S. Department of Energy.

\author{
Information Services \\ Princeton Plasma Physics Laboratory \\ P.O. Box 451 \\ Princeton, NJ 08543
}

Phone: 609-243-2750

Fax: 609-243-2751

e-mail: pppl_info@pppl.gov

Internet Address: http://www.pppl.gov 